\title{
Nanotechnology: Societal and Environmental Impact
}

\author{
LINDA L WILLIFORD PIFER, KATHLEEN KENWRIGHT
}

ABBREVIATIONS: EPA= Environmental Protection Agency; HEPA = High Efficiency Particulate Attenuator; $\mathrm{MIT}=$ Massachusetts Institute of Technology; MSDS= material safety data sheets; NMSP = Nanoscale Materials Stewardship Program; CSIRO $=$ Common wealth Scientific and Industrial Organisation

INDEX TERMS: nanoparticles; nanotechnology; nanodust; nanowaste, nanosafety

\section{LEARNING OBJECTIVES:}

1. Relate how nanotechnology and its advent have impacted our views of the future.

2. Explain environmental concerns about nanotechnology.

3. Address environmental protection issues, and regulatory agencies that are responsible.

4. Describe how nanotechnology is evident in our present society and where it can go in the future.

5. Summarize the changes that are coming, as a result of nanotechnology.

Clin Lab Sci 2010;23(2);117

Linda L. Williford Pifer, Ph.D.,SM(ASCP), GS(ABB), University of Tennessee Health Science Center, Memphis, TN 38163

Kathleen Kenwright, MS, MT,MP(ASCP) SI , University of Tennessee Health Science Center, Memphis, TN 38163

Address for Correspondence: Linda L. Williford Pifer, Ph.D.,SM(ASCP), GS(ABB), Professor of Clinical Laboratory Sciences, University of Tennessee Health Science Center, 930 Madison Avenue, Suite 672, Memphis, TN, 38163,901-448-6338.,lpifer@uthsc.edu
Overview of Nanotechnology and Society

V. Colvin, Director of the Center for Biological and Environmental Nanotechnology at Rice University made the following statement about nanoparticles: "It is a mistake for someone to say nanoparticles are safe, and it is a mistake to say nanoparticles are dangerous. They are probably going to be somewhere in the middle. And it will depend very much on the specifics". ${ }^{1}$ Another phenomenon-defining quote is from Dr. Alexandra Navrotsky, who is the director of the Nanomaterials in the Environment, Agriculture and Technology Organized Research Unit (NEAT ORU) at the University of California at Davis: "Nanoparticles are everywhere. You eat them, drink them, breathe them, pay to have them, and pay even more to get rid of them". 2

Having addressed this issue, where do we go from here? The answer is, go to the scientific literature and determine what is proven, unproven and what is just speculative. In the following paragraphs, we will travel back and forward in time to establish the foundations of what we presently know about nanotechnology, and where it will probably project us into the future.

We must review the past to expound upon where we are at present with this astounding new technology. We will objectively address the "doomsayers" and the optimists.

Role of Nanotechnology in Combating Societal and Environmental "Collapse"

In October, 2009, Sanchez (Columbia University) stated that "...the world population will reach a level of consumption that is unsustainable with the current amount of natural resources available...". ${ }^{3}$ Is this a redux of Thomas Malthus's 1798 theories about population "overload" and possible global doom of mankind on this planet? ${ }^{4}$ In 1798, Malthus predicted 
the same outcome as Sanchez. Malthus predicted that population growth was exponential; while the production of food was linear. ${ }^{3}$ Tragedy never came to pass, because Malthus neither forecast the industrial revolution, which relieved many pressures, nor the advent of birth control. Both of these factors eased economic and societal pressures.

However, in an article by Kushnerov (2009), Pedro Sanchez, director of tropical agriculture and the environment program at Columbia University, predicts gloom and doom in a "world unsustainable by 2050 ". He raises issues such as methane production by cattle, excessive farming, the clearing of land and excessive use of fertilizers and other agricultural chemicals, which he is concerned, will cause major droughts due to water needs. According to Sanchez' projections, food shortages appear to loom in the future. ${ }^{3}$ According to Bielo, we are dealing with possible impending disaster. ${ }^{4}$ He states that by 2050, “...the world will host nine billion people...". ${ }^{4} \mathrm{He}$ goes on to say that “...at least one billion people are chronically malnourished or starving" (Figure 1). ${ }^{4}$

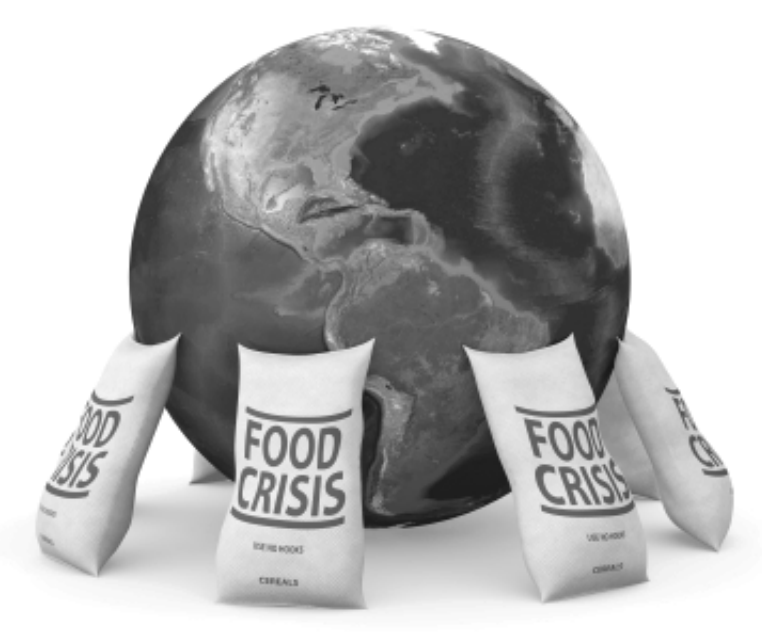

Figure 1. Impending food shortage.

Conversely, this does not take into account genetic engineering that has produced "golden rice", which is rich in vitamin $A$, and has been rejected by some African nations who are suspicious that this is an attempt at genocide fomented by the West. This rice is much needed in developing countries, where vitamin A deficiency has reduced the vision of millions. ${ }^{5}$ Genetic engineering of food crops has been highly controversial in developing nations and in Europe, in particular. They are deemed "Frankenfoods", though there is no evidence to support fearing them for any scientificallybased reason. ${ }^{6}$ Although this does not necessarily relate directly to nanotechnology, it does indicate that technology has the potential once again, to "save the day."

So what is the origin of gloom and doom? In 1972, a book was published entitled "The Limits to Growth", which discussed the rapidly expanding world population and limits to food production, by $\mathrm{D}$. Meadows, et al. The book was the product of an economics group called "The Club of Rome". The book's projections were immediately attacked by RM Solow (MIT), A Kneese and R Riker of Resources for the Future. ${ }^{7}$ They concluded that Meadows et al. had "loaded" the data by projecting that population and pollution would "grow exponentially", and not taken advancing technology into account. HC Wallich, a Yale economist, termed the book "a piece of irresponsible nonsense". ${ }^{8}$

However, in 2008, several of the original authors of the 1972 "Limits" book published an update entitled "Limits to Growth: The Thirty Year Update". In the same year, Graham Turner of the Commonwealth Scientific and Industrial Organisation (CSIRO) published a paper about the new "Limits" book entitled "A Comparison of 'The Limits to Growth' with Thirty Years of Reality". ${ }^{10}$ His interpretation of the thirty-year update was that the original authors were correct thirty years ago. He found their projections of the changes in food production, pollution and industrial production were consistent with economic and societal collapse in the twenty-first century, and thus agreed with Meadows, et al.

Finally, today, where does this leave us? The controversy rolls on, as does the related issue as to whether or not global warming is occurring or if this is merely a momentary geologic/atmospheric "hiccup". If it is legitimately occurring, is human society responsible? 
It is beyond the scope of this paper to attempt to answer these complex issues, but rather, to shed light on nanotechnology's potential to either correct or worsen our environmental and societal future. If technology saved us from Malthusian disaster several centuries ago, then can it once again free us from these threats to our safety and well-being on this planet?

In the thirty-year update, Meadows, et al. conclude this: "Overshoot cannot be sustained without collapse". In other words, our present status may not be sustainable without new technology and drastic changes in the way that we manufacture things, produce food and energy and manage the environment.

According to Meadows et al, “...there are five major elements of global concern: accelerating industrialization, rapid population growth, widespread malnutrition, depletion of non-renewable resources and a deteriorating environment."

Here is where nanotechnology, the new singularity, comes into the picture. How will it impact the sustainability of our society and environment? We may very well find that nanotechnology will help us to overcome these five apocalyptic "horsemen". Technology saved us from the predicted Malthusian disaster, and it can likely do it again, as long as nanotechnology is not allowed to run amok.

\section{Regulation of Nanotechnology}

There are, however, those who damn nanotechnology because they fear and do not understand what is involved. The truth is most likely this: nanotechnology, approached scientifically and with care, will most likely present more benefits than hazards. Scientific fact, based upon observation and the collection of data, will provide the answers and ultimate conclusions.

The "fog" of nanotechnology has come, as Carl Sandburg said, on "little cat feet..."11. It is already here, and has entered our lives mysteriously. Interestingly enough, it appears to have "crept in" before the regulatory agencies were fully formed and cognizant of its existence and potential. Is this a bad thing? At present, this is terra incognita. We should neither remain ignorant nor be swayed by popular opinion. Only the data will reveal the truth.

As early as 2006, and perhaps earlier, scientists have focused upon the effects of nanotechnology on the environment, and some very good ideas have emerged. 12 Nanotechnology-based techniques are being developed to detect and filter out air pollutants. ${ }^{12}$ Paint industry representatives said that nanoparticles could be incorporated in coatings that would save energy, and would help to "... reduce heat loss by reflecting infra-red radiation, or to produce 'smart paints' that change color when exposed to changes in temperature and light." ${ }^{12}$

Gradually, we are coming to terms with the need for regulation in nanotechnology research and development. On January 28, 2008, the EPA “...launched a program...for voluntary reporting of engineered nanomaterials. The Nanoscale Materials Stewardship Program (NMSP) requests that firms submit information to the agency within six months."13

On Sept. 29, 2009, the EPA announced that they will project "...a new research strategy to better understand how manufactured nanomaterials may harm human health and the environment." ${ }^{14}$ At present, nanomaterials are used in hundreds of consumer products, including cosmetics, sunscreen and sports equipment such as tennis rackets and bicycle frames. ${ }^{14}$ An MIT website states that toxicology studies at this point in time conclude that "...some types of nanomaterials can be toxic, if they are not bound up in a substrate and they are available to the body." ${ }^{15}$ The same site also states that there are "currently no government occupational exposure standards for nanomaterials." They also point out that different standards for different types of nanomaterials will be needed, and that all should be aware that their MSDS's "...may not have accurate information at this time." In the meantime, these experts recommend the use of ventilated enclosures such as fume hoods and respirators containing HEPA filters. A role is also seen for employing vacuum and exhaust devices and thorough skin protection.

Another potential safety concern addresses materials spread through explosions or fires. This may become 
more concerning when reactions are scaled to industrial levels. "Nanodusts can be anticipated to have a greater potential for explosivity than larger particles." 15 Determination of lower flammability limits is being planned in Europe ${ }^{15}$. No one wants to run the risk of Chernobyl- (nuclear meltdown) and Bhopal-type (chemical poisoning) environmental disasters with nanomaterials. MIT appears to have taken a leadership role in the management of nanowastes. No nanomaterials are disposed of down drains or into the "regular" trash. Presence of toxic elements such as silver and cadmium or flammable materials is taken into consideration. Finally, "The Environment at MIT" website provides many additional sources of information. ${ }^{15}$

\section{"Green" Nanotechnology}

In 2008, a NanoCap Working Conference focusing upon ethical and societal challenges of nanotechnologies met in Darmstadt, Germany. The conference title was "What Makes Green Nanotechnology so Smart?" Desirable strategies discussed included "producing nanomaterials without harming the environment or human health" and "producing nanoproducts that provide solutions to environmental challenge." It was further suggested that nanomaterials be used as catalysts for greater efficiency in current manufacturing process (green chemistry principles), that nanomaterials should be employed for more efficient alternative energy production (solar and fuel cells), and that the synthesis of nanoparticles from microbes and dead or living plants be accomplished. One product showcased at the conference was Greenyarn Short Socks. They were termed "Eco-fabric socks" that "...deodorize, resist bacteria and fungi, and help blood circulation". ${ }^{16}$

A "green" research project funded by the Air Force Office and the National Science Foundation is attempting to generate electricity from the exhaust gases of military turbine aircraft. If they succeed, it will be a "win-win" endeavor, and may prove that we can "have our cake and eat it, too". Electricity, whose production too often causes toxic emissions, will actually use these exhaust gases, providing extremely clean and "green" energy. ${ }^{17}$
In conclusion, we are facing a double-edged sword. This is usually the case with newly emerging technologies, which promise amazing power. The Sword of Damocles ${ }^{18}$ stands suspended above our heads. With great power comes great potential risk and gain. Do we embrace the new technology, or do we defer to fear, including societal and environmental concerns? Again, we need to trust the scientific data. There are many issues on the table. We have profit-driven groups who could realize enormous financial gain, and might not be as sensitive to human safety and environmental issues as we would like. There are practical concerns: How can nanotechnology enable us to live "greener" and more environmentally safe lives? Is nanotechnology the dream of the future that will release us from fears of global starvation and the potential collapse of society?

It will probably be best to move forward cautiously. There are many unknowns. There are "promises to keep," and “... miles to go before (we) sleep". ${ }^{19}$

\section{REFERENCES}

1. Mit.edu. Massachusetts: MIT EHS-Nanomaterials. Available from http://web.mit.edu/environment/ehs/topic/nanomaterial. html [cited Oct 16, 2009].

2' Navorotsky A. What is NEAT? Nanomaterials in the Environment, Agriculture \& Technology (NEAT) ORU Available from http://neat.ucdavis.edu/index.htm Jul 1, 2009 [cited Oct 16, 2009].

3. Kushernov A. World unsustainable by 2050. Available from http://www.theticker.org/about/2.8220/world-unsustainableby-2050-1.1993307 Oct 12. 2009 [cited Oct 16, 2009].

4. Biello D. Another Inconvenient Truth: The World's Growing Population Poses a Malthusian Dilemma, Available from http://www.scientificamerican.com/article.cfm?id=growingpopulation-poses-malthusian-dilemma. Scientific American Oct 2, 2009 [cited Oct 27, 2009].

5. Golden rice.org. Golden Rice Project Home Page; Golden rice is part of the solution. Available from http://www.golden rice.org/ [cited Dec 1, 2009].

6. Poulter S. Alert over the march of the 'grey goo' in nanotechnology Frankenfoods. Available from http://dailymail. co.uk/sciencetech/article-505561/Alert-march-grey-goo-nanotechnology-Frankenfoods.html. Mail Online Jan 02, 2008 [cited Dec 1, 2009].

7. Solow RM, Kneese A, Riker R. Resources for the future. Newsweek 1972; Mar 13; 103.

8. Wallich HC, To Grow or not to Grow. Newsweek 1972; Mar $13 ; 102-3$.

9. Meadows DH, Meadows DL, Randers J. Limits to Growth: The 30-year update. White River, VT: Chelsea Green Publishers; 2004. 
10. Turner GA. Comparison of 'the limits to growth' with 30 years of reality. Commonwealth Scientific and Industrial Research Organization. Australia, 2008 [cited Oct 16, 2009].

11. Sandburg C. The complete poems of Carl Sandburg. Wilmington MA: Houghton Mifflin Harcourt; 2003.

12. Maynard A. Nanotechnology: assessing the risks. Nanotoday. 2006;1: 22-3.

13. EPA Launches Nanoscale Materials Stewardship Program. Available from http://enewsusa.blogspot.com/2008/01/epalaunches-nanoscale-materials.html. eNewsUSA. Jan 28, 2008 [cited Oct 15, 2009].

14. Kemery D. EPA announces research strategy to study nanomaterials. Available from http://yosemite.epa.gov/opa/ admpress.nsf/d985312f6895893b852574ac005f1e40/3058183 a44280171852576400076bc35!OpenDocument.Environment al Protection Agency, Sep 29, 2009 [cited Dec 2, 2009].

15. The Environment at MIT. Potential risks of nanomaterials and how to safely handle materials of uncertain toxicity Available from http://web.mit.edu/environment/ehs/topic/nanomaterial .html. Apr 7, 2009 [cited Oct 16, 2009].
16. Schwarz AE What makes green nanotechnology so smart? Proceedings of the NanoCap Working Conference "Ethical and Societal Challenges of Nanotechnologies" Darmstadt, Germany. Available from: http://www.nanocap.eu/Flex/Site/ Download.aspx?ID=4739. Sep 10-12, 2008

17. Nanotechnology Development Blog Available from http://www.nanotechnologydevelopment.com/research/researc hers-are-working-to-develop-eco-friendly-thermoelectricsell.html. Oct 18, 2009; cited Oct 27, 2009].

18. Westall R. The Sword of Damocles. Ackland Art Museum University of North Carolina Chapel Hill. Available from: http://www.ackland.org/tours/westall.html.

19. Frost R. Stopping by woods on a snowy evening. New York: Henry Holt and Company 1923.

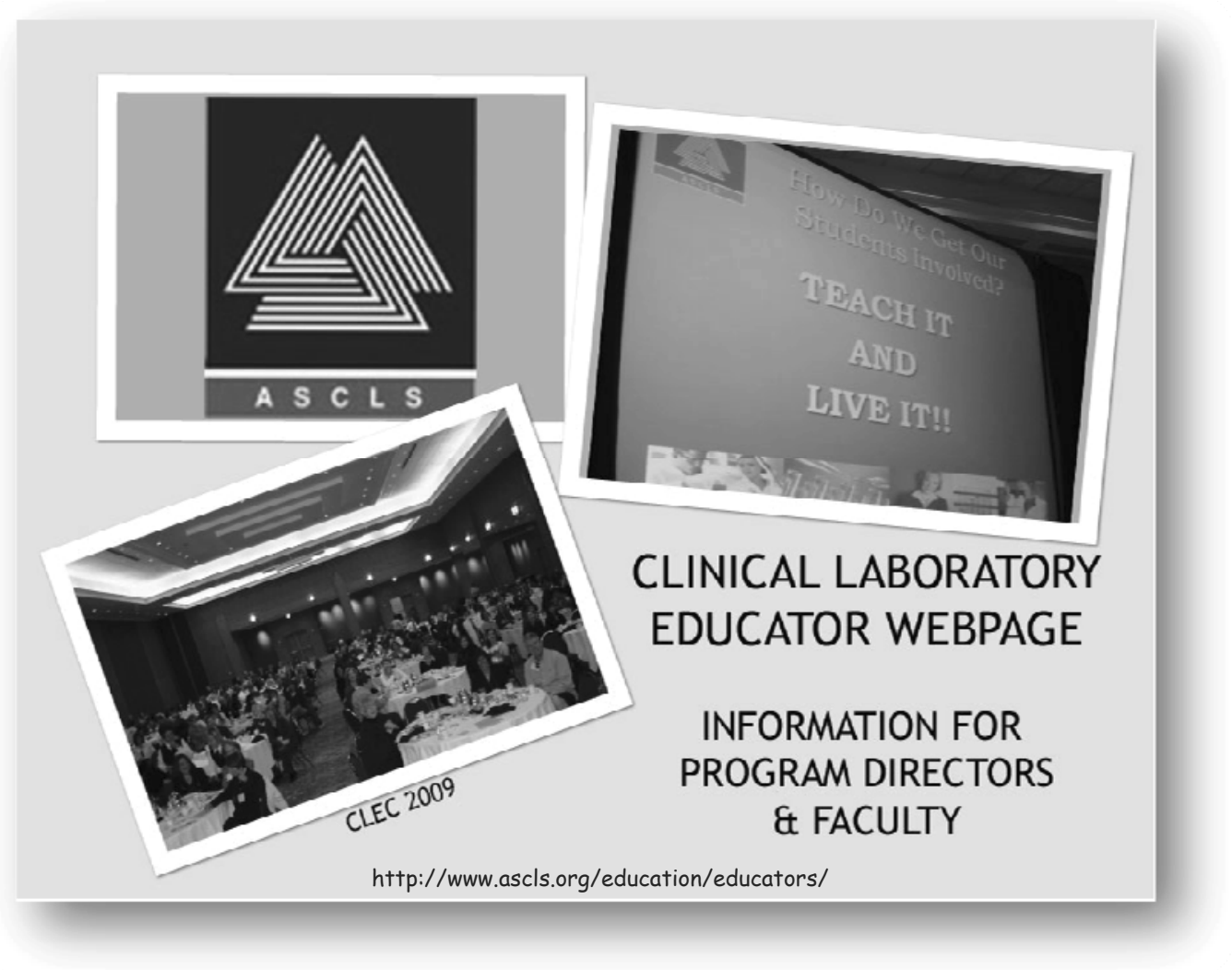

